\title{
CORRUPTION PREVENTION BASED ON E-GOVERNMENT WITH ISLAMIC RELIGIOSITY AS A MODERATING VARIABLE
}

\author{
Chrisna Suhendi $^{1}$, Abdul Rohman ${ }^{2}$ and Agus Purwanto ${ }^{3}$ \\ ${ }^{1}$ Faculty of Economics, Sultan Agung Islamic University-Semarang 50012, \\ Ph.D Student of Diponegoro University-Semarang, Indonesia \\ E-mail: chrisnasuhendi@unissula.ac.id \\ ${ }^{2}$ Professor and Lecturer of Economics and Business Faculty, \\ Diponegoro University, Semarang 2011, Indonesia \\ E-mail: abdulrohman@live.undip.ac.id \\ ${ }^{3}$ Lecturer of Economics and Business Faculty, Diponegoro University, \\ Semarang 2011, Indonesia \\ E-mail: agsp_sis@yahoo.com
}

\begin{abstract}
The growing phenomenon of corruption in Indonesia was used as a basis of this research. This study aimed to examine the effect of e-government on corruption and the role of Islamic religiosity in moderating the relationship between e-government and corruption. The research data was obtained through a survey of 133 of 869 Budget Users (PA) at the Local Government Work Unit (Organisasi Perangkat Daerah, OPD) in Central Java Province. Data analysis in this research used the SPSS 16 software aid with the Moderated Regression Analysis (MRA) Test, ie pure moderated test. This research formulated 2 hypothesis. The test results showed that e-government has no direct negative effects in reducing corruption, but Islamic religiosity plays a role in moderating the relationship between e-government and corruption in order to reduce corruption.
\end{abstract}

Keywords: e-government, islamic religiosity, corruption

ARTICLE INFO

Article History:

Received: 28 November 2019

Accepted: 31 March 2020

Published: 30 April 2020 


\section{INTRODUCTION}

The Indonesian Corruption Watch (ICW) in 2015 noted that since 2012 until 2014 the number of suspects in corruption cases continued to increase. Various attempts to reduce the level of corruption have been done in Indonesia, for example the establishment of the Corruption Eradication Commission (KPK). The effort should be able to decrease the level of corruption, but the phenomenon of corruption not only continue to exist but is increasing. Improvements in any activities is ineffective in preventing corruption. Bribery is considered as a small outlay in order to get greater results (Indriati, 2014). Why corruption still exists?. The Fraud Theory was first proposed by criminologists, Cressey (1950) writing that there are 3 (three) factors why people commit fraud, that is: Motivation (Pressure); opportunity; and rationalization. Based on this theory by Cressey, then rationally, corruption can be prevented by eliminating the three sources.

From an economics perspective, to eliminate any opportunity in corruption, good governance is most appropriate to address this problem (Wilopo, 2006). By using Information and Communication Technologies (ICTs), governance will run more effectively and efficiently. Governance using information technology is called e-government. E-government is believed to be able to prevent or reduce corruption. The e-government concept for preventing corruption has been proven by many researchers such as Colby (2001), Chaurasia (2003), Budhiraja (2003) and Millard (2004). Likewise, research from Cho and Choi (2004), Bhatnagar (2004); Csáki and Gelléri (2005); Pathak and Prasad (2006); and Bhatnagar, Rao, Singh, Vaidya, and Mandal (2007) proved the same thing that e-government can reduce corruption.

However, there is some evidence that the use of information and communications technologies (ICTs) in governance can also increase the chances of corruption, and constitute a new model of corruption (Heeks, 1998). According Heeks (1999), although ICTs have been applied to prevent corruption, corruption still exists. Furthermore, Rotchanakitumnuai (2013) stated that he did not dare to guarantee that the use of e-government Procurement (e-GP) can reduce corruption. Suartana (2010) acknowledged that implementation of principles of good governance are still encountering many obstacles, mainly due to human behavior. Such an opinion has 
already been given by Vaidya, Sajeev, and Callender (2006). He stated that "Humans" have the most prominent success factor of e-governance implementation. This implies that there are other factors that play a significant role in preventing corruption.

Corruption is also the phenomenon of the human degradation process because it breaks trust between humans (Dion, 2011). Corruption is a complex issue, therefore, to prevent and combat it requires a solution from a variety of approaches such as the approaches in Sociology, Anthropology, Psychology, Politics, Culture, Law, Ethics / Moral and Economic (Jain, 2001; Ramamoorti, 2008).

In general, studies on an economic perspective have not touched on the religious perpetrators of corruption. The level of religious corruptors can also motivate actions in its activities. Emerson and Mckinney (2010) said that religion is important for establishing an ethical bussiness attitude. They also stated that God knows and sees what we do, so unethical behaviors can be minimized/avoided. Corruption is unethical individual behavior. Ethical or unethical behavior is clearly a choice. An individual has a right to make decisions as he/she wishes. The role of religion to prevent deviant behavior has been investigated by some researchers such as Cochran (1988), Fam, Waller, and Erdogan (2004), Dyreng, Mayew, and Williams (2010) and Desmond, Ulmer, and Bader (2013).

Religion, especially Islam considers that corruption is not acceptable. Prohibition of corruption can be seen in several verses on the Qur'an and Hadith $^{l}$. Although textual meaning of the word corruption does not directly exist, verses and hadiths describe definition of corruption by using analogy. Corruption act (ghulul) can be categorized as consuming human treasures by the wrong way and forbidden by Allah Subhanahu wa Ta'ala, as the words in the Quran surah (chapter) al-Baqarah verse 188 state as follows:

"And do not some of you take the treasure among you by way of vanity, and do not bring (business) treasure it to the judge, so that you can eat some from possessions of others with (the act) sin, whereas you know"

(al Baqarah 2:188).

1 Statements or actions of Prophet Muhammad (pbuh) 
Moreover, there is also hadith addresses corruption. One of the hadiths is from 'Adiy bin' Amirah Al Kindi Radhiyallahu 'anhu. He said: I heard the Prophet sallallaahu' alaihi wa sallam said:

"Whoever among you that we assign to a job (business), and then he hid from us a needle or more than that, then it is ghulul (shackles, treasure corruption) that he will bring on the Day of Judgment".

Based on the above background, the purpose of this study was to examine the role of Islamic religiosity and e-government in preventing corruption

\section{LITERATURE REVIEW}

The first Fraud Theory was raised by Donald R. Cressey in 1950. Cressey (1950) wanted to know why people betrayed trust. Serious financial problems faced by perpetrators and not be shared to anyone else can make people to be traitors. The perpetrator then realizes that financial problems can be solved by foul means. Then the perpetrator creates a perception for himself that he/she is only borrowing and not stealing. That is the hypothesis proposed by Cressey. Financial problems is known as first factor i.e. pressure factor. The second factor is the opportunity factor. It describes chance to violation. Then third factor is the rationalization factor. It describes justification of dishonest actions. The hypothesis was known as the Fraud Triangle, and it is used as a rationale for why people commit fraud.

Defining corruption is a matter of long debate. There are many definitions of corruption. Among the more famous definitions of corruption is the one offered by Nye (1989): "Behavior which deviates from the formal duties of a public role because of private regarding (personal, close family, private clique) pecuniary or state gains; or violates rules against the exercise of certain types of private-regarding influence". Here we define corruption as any type of illegal action or step to get a legal service, facility, or right.

Ojha, Palvia, and Gupta (2008) conducted research based on research reports on the impact of e-government on corruption. Research results by Iqbal and Seo (2008); Bhatnagar et al. (2007); NeGP Report (2007); Pathak 
and Prasad (2006); Csáki and Gelléri (2005); Bhatnagar (2004); Cho and Choi (2004); and Heeks (1999) on the impact of e-government were then summarized and analyzed by Ojha et al. (2008). Based on the results of the analysis, then Ojha et al. (2008) illustrates the conceptual model for the impact of e-government on corruption. The conceptual model can be seen as follows:

e-Government services

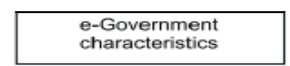

Low asset specificity (\#)

Low uncertainty (\#)

Online availability (\#)

- policy

- procedures

- rules

- forms

- deadlines

Services 365 days $24 \times 7$ (\#)

Disintermediation (\%)

Automated Processing (\%)

Low information asymmetry (\%)

Lower monitoring costs (\%)

Audit Trail $\left(\%{ }^{*}\right)$

- transactions

- interactions

\# relevant in terms of Transaction Cost Economics

$\%$ relevant in terms of Principal Agent Theory

* relevant in terms of Economics of Crime

Figure 1: Conceptual Model by Ojha et al. (2008)

Figure 1 shows that there are three (3) basic potentials in e-government as an anti-corruption model. First, is the types of services present in an e-government, namely G2C (Government to Citizen and vice versa); then G2B (Government to Business and vice versa); and G2G (Government to Government). Second, the characteristics of e-government services such as 24-hour service, online information availability, reducing information asymmetry and others. Third is the benefits of e-government, which is able to reduce corruption, efficient management, as an "early warning" against fraud and so on. In summary the basic theoretical model as shown in figure 1, theoretically, e-government will have an effect on prevention of corruption.

Corruption is aberrant behavior. Deviant behavior can be prevented by religion. This opinion was forwarded by Cochran (1988); Fam et al. (2004), and Desmond et al. (2013). This means that religion has an impact on corruption behavior. 


\section{Islamic Religiosity and Taqwa Concept}

\section{Islamic religiosity}

Individual behavioral patterns which are different with others reflects a belief value of individual. An individual belief is based on their choice (Allport \& Ross, 1967). So, a value can be considered as part of an individual's personality (Azwar, 2012). Values adopted by individuals refers to individual value, while values adopted by most of society is called social value.

Ancok and Suroso (1994) states that there are two types of values i.e. extrinsic and intrinsic values. Extrinsic values is classified into five perspectives i.e. theoretical values, economic values, social values, political values and religious values. Religious values reflect that truth is derived from God. Furthermore, Ancok and Suroso (2011) mention that the intrinsic values is divided into five, i.e. a practical values, educational values, intellectual capital values, socio-political values and religious values. Religious value is a value that inspires confidence and faith of an individual. This values imply that everything is already organized by God.

Every human being has a different type of faith. These differences are labelled by psychologists as Religious Orientation. Religious orientation refers to a faith approach, meaning that what is the meaning of faith in one's life (Paloutzian, 1996). Religious orientations are divided into two concepts. First, is the intrinsic religious orientation, which related to if a person lives a life in accordance with his/her religion. An intrinsic religious orientation reflects that one's faith comes from within the person. Second, extrinsic religious orientation, means that someone is utilizing religion to live. Such people tend to exploit religion for themselves (Paloutzian, 1996).

People with intrinsic religiosity can be categorized as those who have reached personal maturity and integrity at a certain level. They have made a commitment to religion without reservations and make decisions independently. Psychologically, religious orientation becomes a part that can not be separated from one's religious maturity.

Rakhmat (2004) cited in C.Y. Glock in his "On the Study of Religious Commitment: Review of Recent Research on Religious Bearing Character 
Formation" (1962) and developed five-dimensional model of religiosity. $\mathrm{He}$ classified religious into five dimensions, i.e. ideological, ritualistic, intellectual, experiential, and consequential. Ismail (2012) stated that religious people who have the five religious dimension as mentioned above, in the Islamic context are called as taqwa (piety) and are totally religious or kaafah. In terms of psychology it is known as integral and comprehensive.

\section{Taqwa concept}

The concept of taqwa will be understood easier if it is done through the study of etymology, terminological and Quranic comprehensively. Etymologically, the word taqwa is mentioned in the Qur'an 258 times (Shaleh, 2008). Taqwa could mean maintain, preserve, protect, carefully, keep far away from something, and fear of punishment. Taqwa interpreted as fear of punishment means fear of punishment from Allah. It has a consequence for individuals to do all the commands of Allah and stay away from all prohibitions. Shaleh (2008) argued that taqwa is an inner and outer consciousness. It implies that one has to obey all commandments and stay away from all prohibitions with full sincerity, according to human ability.

According to the Qur'an, taqwa has several meanings. Taqwa can mean a fear (Surah 31:33), faith (Surah 48:26), repentance (Surah 7:96), obedient / submissive (Surah 16: 2), leaving disobedience (Surah 2: 189), sincere (Surah 22: 32).

Shaleh (2008) says that based on the Qur'an Surah (Q.S.) al-Baqarah verses 2-5 and verse 177; Q.S. Ali-Imran verses 15-17, 133-135; Q.S. alZumar verse 33; and Q.S. al-Dzariat verses 15-19 there are 15 characteristics of the human being cautious, i.e. :

(1). Godly (2). Worship. (3). Zakat. (4). Spend out of their wealth. (5). Keeping promises. (6). Patient. (7). Pray to God. (8). correct. (9). Remain obedient to God. (10). Remember, istighfar, and repentance to God. (11). Keep one's temper. (12). Forgiving. (13). Doing good. (14). Not continuing his evil deeds. (15). Tahajud prayer.

Shaleh (2008) wrote on matters that can form a taqwa attitude as well as matters that can damage taqwa. Associated with activities that can form a taqwa attitude, Shaleh noted that there are eight activities, i.e.: (1). 
Reading and Reviewing the Al-Qur'an, (2). Hold firmly and implement the contents of the Al-Qur'an. (3). Always be in Oneness with God. (4). Always remember the commands of Allah, (5). Istiqomah (consistent). (6). Worship Allah, (7). Qisas implementation, and (8). Fasting. Whereas, activities that break taqwa is divided into five, i.e.: (1). Kufr, (2). Shirk, (3). Deniers of God and Messenger, (4). Fisq and Fusûq, (5). Nifaq.

People who live life based on religion and have an intrinsic orientation, will have personal maturity and religious maturity. Religion and faith is seen as a necessity inherent in every action and a part that can not be separated. Intrinsic religious people will put faith into their personal life and assess life in this world transcendentally. These conditions make intrinsic people behave qona'ah (affluent), so corruption will not be done by the pious.

Based on the explaination above, theoretically, it is believed that piety of someone would prevent a person from involving in corruption. As taqwa is expected to reduce the possibility of someone to involve in corruption, it seems that e-government and Islamic religiosity may limit the incidence of corruption.

\section{HYPOTHESIS DEVELOPMENT}

Based on the literature review as described above, the hypothesis is summarized as follows:

\section{Effect of e-Government on Corruption}

The rapid development of ICTs has made the implementation of good governance more effective and efficient. E-government can increase transparency, create a new culture and behavior, and close all opportunities for "middleman" or intermediaries, and also provide integrated information. The results of the research by Iqbal and Seo (2008) show that e-government can act as an anti-corruption tool. So, the hypothesis is proposed as follows:

$\mathbf{H}_{1}$ : E-government has a negatif effect on corruption. 


\section{The Role of Islamic Religiosity in Moderating the Relationship between e-Government and Corruption}

Every human being has a different pattern of faith. The difference in the pattern of faith is referred to by psychologists as Religious Orientation. Religious orientation refers to one's faith approach, meaning what faith means in one's life (Paloutzian, 1996). Religious orientation is divided into two concepts, i.e intrinsic and extrinsic orientation. Intrinsic religious orientation is someone whose life is based on religion. People with intrinsic orientation can be categorized as people who have reached a certain level of personal maturity and integrity. He/she has made a commitment to to his/ her religion unconditionally and makes decisions independently. Eventually, the person will not take deviant actions. Research done by (Cochran, 1988); Fam et al. (2004), and Desmond et al. (2013) shows that religiosity has a negatif effect on corruption.

Hicks and King (2008) argued that religious commitment moderates the relationship of mood and positive influence with meaning in life. Emerson and Mckinney (2010) in their research have proved that religious attitudes and practices affect self-control and reduce deviant behavior. This is closely related to the belief in the existence of a God who is capable of watching every move that is revealed or hidden, so it is very likely that such a believer will be careful in behaving (Carter, McCullough, \& Carver, 2012). Shamsudin, Chauhan, and Maitama (2012) argue that self-control is a moderator of the relationship between formal control systems and workplace deviations.

So, the hypothesis is proposed as follows:

$\mathbf{H}_{2}$ : Islamic religiosity moderates the relationship between e-government and corruption. 


\section{RESEARCH METHODS}

\section{Data}

Population in this research is the Budget User Authority at the Regional Working Unit (Satuan Kerja Peringkat Daerah, or SKPD). The questionnaires were distributed in between October 2017 and January 2018. Due to time constraints, the study managed to collect only 133 completed questionnaires. However, this number is consistent with Sekaran (2006), that suggested the range of sample size should be between 30 and 500 .

\section{Measures}

Three variables namely e-government, Islamic religiosity, and corruption were measured in the study. Table 1 below summarized the operational definition and measurement of these variables:

\section{Table 1: Summary of Operational Definition and Measurement of Variables}

\begin{tabular}{|c|c|c|c|}
\hline No & Variables & Operational Definition & Variable Measurement \\
\hline 1. & E-government & $\begin{array}{l}\text { E-government variable was } \\
\text { defined as government actions or } \\
\text { activities using information and } \\
\text { communication technologies (ICTs) } \\
\text { where citizens have greater access } \\
\text { of effective services and participating } \\
\text { in government, and increase } \\
\text { interaction between government } \\
\text { and citizen. }\end{array}$ & $\begin{array}{l}\text { Implementation of Critical Success } \\
\text { Factors (CSFs) in e-government was } \\
\text { used to measure how far CSFs have } \\
\text { been applied in OPD. }\end{array}$ \\
\hline 2. & $\begin{array}{l}\text { Islamic } \\
\text { religiosity }\end{array}$ & $\begin{array}{l}\text { Islamic religiosity is the depth of } \\
\text { one's religious devotion and its belief } \\
\text { in the existence of God manifested } \\
\text { by obeying the command and away } \\
\text { from the prohibition with the heart } \\
\text { and with the whole body and soul. }\end{array}$ & $\begin{array}{l}\text { Islamic religiosity was measured by } \\
\text { Islamic religiosity devotion (Saleh, } \\
2008 \text { ). It has } 3 \text { dimensions, namely the } \\
\text { dimensions of human character ( } 15 \\
\text { indicators); dimensions of activities } \\
\text { that shape the attitude of piety ( } 8 \\
\text { indicators); and the dimensions of } \\
\text { activities that damage devotion ( } 5 \\
\text { indicators). }\end{array}$ \\
\hline 3. & Corruption & $\begin{array}{l}\text { Corruption is defined as "The act of } \\
\text { requesting (extortion) / obtaining / } \\
\text { giving (bribery) the reward of money, } \\
\text { goods, or privileges (nepotism) } \\
\text { for services that are supposed } \\
\text { to be given or using powers to } \\
\text { achieve goals that are inconsistent } \\
\text { with ethical / moral or regulatory } \\
\text { standards legislation for personal } \\
\text { gain (personal, close family, close } \\
\text { friends) }\end{array}$ & $\begin{array}{l}\text { Corruption was measured by the main } \\
\text { phenomenon of corruption, namely } \\
\text { bribery, extortion that occurs in the } \\
\text { habits of society and the experience } \\
\text { of public service. }\end{array}$ \\
\hline
\end{tabular}




\section{Data Analysis Technique}

The data analysis technique used in this study was the Moderated Regression Analysis (MRA). The Moderated Regression Analysis model used in this study is shown in the following equation:

$$
\operatorname{Crp}=\alpha+\beta_{1} \text { E-Gov }+\beta_{2}(\text { E-Gov x IR })+\varepsilon
$$

Where:

$$
\begin{array}{lll}
\text { Crp } & =\text { corruption } & \text { IR }=\text { Islamic religiosity } \\
\text { E-Gov }=\text { e-government } & \varepsilon=\text { error }
\end{array}
$$

\section{FINDINGS}

\section{The Result of MRA}

The test results for each of the research hypotheses can be explained as follows:

Table 2: Coefficients ${ }^{a}$

\begin{tabular}{|l|l|c|c|c|c|c|}
\hline \multirow{2}{*}{ Model } & \multicolumn{2}{|c|}{$\begin{array}{c}\text { Unstandardized } \\
\text { Coefficients }\end{array}$} & $\begin{array}{c}\text { Standardized } \\
\text { Coefficients }\end{array}$ & \multirow{2}{*}{ t } & \multirow{2}{*}{ Sig. } \\
\cline { 2 - 5 } & B & Std. Error & Beta & & \\
\hline \multirow{2}{*}{1} & (Constant) & 35.351 & 8.964 & & 3.944 & .000 \\
\cline { 2 - 6 } & E-Gov & .194 & .068 & .417 & 2.840 & .005 \\
\cline { 2 - 7 } & E-Gov x IR & -.002 & .000 & -.657 & -4.474 & .000 \\
\hline \multicolumn{2}{|l|}{ a. Dependent Variable: Crp } & & & & \\
\hline
\end{tabular}

Table 2 above shows that e-government has a positive and significant effect. This means that the 1st hypothesis in this study is rejected. In other words, the hypothesis that e-government negatively affects corrupt behavior is not proven. Next, from Table 2 above also shows that Islamic religiosity moderates the relationship between e-government and corruption significantly. This shows that Hypothesis 2 in this research is accepted. In other words, the hypothesis that Islamic religiosity moderates the relationship between e-government and corruption is proven. Briefly it can be said that 
corruption can not be prevented by e-government, but e-government which is accompanied by high Islamic religiosity can decrease corruption.

\section{DISCUSSION}

\section{Effect of e-Government on Corruption}

The results of this study indicate that although the implementation of e-government in OPD is getting better, corruption does not seem to be eradicated. E-government variable that is formed from CSFs indicator have not been able to decrease perception of corrupt behavior. In this study, corruption behavior is measured based on the respondent's perception on their community including family, community and public, on corruption. Majority respondents indicated that the habit of giving money to religious leaders, and others are still common especially during celebration or religious festivals. It seems that it is a habit that is difficult to be eliminated in the community. Therefore, "Gift-Giving" habit is still common among general public in Central Java Province, Indonesia.

The results of this study differ from researchers such as Colby (2001), Chaurasia (2003), Budhiraja (2003), Millard (2004), Cho and Choi (2004), Bhatnagar (2004); Csáki and Gelléri (2005); Pathak, and Prasad (2006); and Bhatnagar et al. (2007) which proved that e-government is able to reduce corruption. But, this research is in line with Heeks (1999). Although ICTs have been applied to prevent corruption, corruption still exists. Similarly, this research is in line with Rotchanakitumnual (2013), who does not guarantee that the use of e-government procurement (E-GP) can reduce corruption.

Thus the results of this study indicate that although there is more sophisticated technology, corruption still exist. The case in Indonesia on E-ID card provides evidence that corruption still exists, and the media had reported that the E-ID card case is the biggest corruption revealed over the past 2 years. 


\section{The Role of Islamic Religiosity in Moderating the Relationship Between e-Government and Corruption}

This research successfully tested that Islamic religiosity in moderating the relationship between e-government and corruption. The result of statistical test shows that the proposition that Islamic religiosity and e-government can decrease corruption is accepted. This can be seen in regression coefficients that are marked (-) and significant at the $\alpha=0.05$ level. Negative regression means that Islamic religiosity is able to influence the e-government in reducing Corruption. This is in accordance with the proposed hypothesis that Islamic religiosity moderates the relationship between e-government and corruption. Based on the results of statistical tests, it can be concluded that sophisticated ICTs coupled with individuals who have a high Islamic religiosity will be able to encourage individual behavior to reduce corruption.

The results support the opinion of Hicks and King (2008) who stated that religiosity of an individual may influence an individual behavior. Emerson and Mckinney (2010) proved in their research that the attitudes and practices of religion affect self-control and reduce deviant behavior. While Shamsudin et al. (2012) argued that self-control is a moderator of the relationship between formal control systems and workplace deviations. This is closely related to the belief in the existence of a God who is capable of watching every move that is revealed or hidden, so it is very likely that such a believer will be careful in behaving and behaving (Carter et al., 2012).

Religious adherence based on high Islamic religiosity becomes very important for a Budget User (PA). He will feel always being watched by God, so he will have control of himself against his behavior.

\section{CONCLUSION}

This study intended to examine the effect of e-government on corruption and the role of Islamic religiosity in moderating the relationship between e-government and corruption. This study found that the e-government approach solely might not be able to reduce corruption. However, it was also found that Islamic religiosity was able to moderate the relationship between 
e-government and corruption. In other words, e-government was viewed as an effective mechanism to combat corruption, if there was element of religiosity in the user of the system. However, as the study focus only in Central Java, Indonesia, more robust study should be conducted in the future.

\section{REFERENCES}

Allport, G. W., \& Ross, J. M. (1967). Personal religious orientation and prejudice. Journal of Personality and Social Psychology, 5(4), 432-443.

Ancok, D., \& Suroso, N. F. (1994). Psikologi Islami. Jakarta: Pustaka Pelajar.

Ancok, D., \& Suroso, N. F. (2011). Psikologi Islami. Yogyakarta: Pustaka Pelajar.

Azwar, S. (2012). Sikap manusia-teori dan pengukurannya (2 ${ }^{\text {nd }}$ ed.). Yogyakarta: Pustaka Pelajar.

Bhatnagar, S. C. (2004). E-government: From vision to implementation - A practical guide with case studies. New Delhi, India: Sage.

Bhatnagar, S. C., Rao, T. P., Singh,N.,Vaidya, R., \& Mandal, M. (2007). Impact Assessment study of e-government projects in India. Ahmedabad, India: Center for e-Governance, Indian Institute of Management, Ahmedabad.

Budhiraja, R. (2003). Electronic Governance - A key issue in the 21st century. A paper by Additional Director, Electronic Governance Division Ministry of Information Technology, Government of India.

Carter, E. C., McCullough, M. E., \& Carver, C. S. (2012). The mediating role of monitoring in the association of religion with self-control. Social Psychological and Personality Science, 3, 691-697.

Chaurasia, A. R. (2003). Information Technology in Governance. Potentials and Prospects. Centre for Excellence in Information Technology, Academy of Administration and Management, Bhopal. 
Cho, Y. H., \& Choi, B. D. (2004). E-government to combat corruption: The case of Seoul metropolitan government. International Journal of Public Administration, 27(10), 719-735.

Cochran, J. K. (1988). The effect of religiosity on secular and ascetic deviance. Sociological Focus, 21(4), 293-306.

Colby, S. S. (2001). Anti-corruption and ICT for good governance. Deputy Secretary-General. OECD in Anti-Corruption Symposium.

Cressey, D. R. (1950). Criminal Violation of Financial Trust (PhD Thesis). Indiana University, Department of Sociology.

Csáki, C., \& Gelléri, P. (2005). Conditions and benefits of applying decision technological solutions as a tool to curb corruption within the procurement process: The case of Hungary. Journal of Purchasing and Supply Management, 11(5-6), 252-259.

Desmond, S. A., Ulmer, J. T., \& Bader, C. D. (2013). Religion, self control, and substance use. Deviant Behavior, 34(5), 384-406.

Dion, M. (2001). Corruption, fraud and cybercrime as dehumanizing phenomene. International Journal of Social Economic, 38(5), 466-476.

Dyreng, S. D., Mayew, W. J., \& Williams, C. D. (2010). Religious social norms and corporate financial reporting. AAA 2010 Financial Accounting and Reporting Section (FARS) Paper. Retrieved from http:// ssrn.com/abstract=1444839

Emerson, T. L., \& Mckinney, J. A. (2010). Importance of religious beliefs to ethical attitudes in business. Journal of Religion and Business Ethics, $1(2), 1-15$.

Fam, K. S., Waller, D. S., \& Erdogan, B. Z. (2004). The influence of religion on attitudes towards the advertising of controversial products. European Journal of Marketing, 38(5/6), 537-555. 
Heeks, R. (1998). Information age reform of public sector: the potential and problems of IT for India (Working Paper series, Paper No. 6). Information Systems for Public Sector Management.

Heeks, R. (1999). Information technology and the management of corruption. Development in Practice, 9(1-2), 184-189.

Hicks, J. A., \& King, L. A. (2008). Religious commitment and positive mood as information about meaning in life. Journal of Research in Personality, 42(1), 43-57.

Indriati, E. (2014). Patterns and roots of corruption "Destroying the circle of satan public sins”. Jakarta: PT Gramedia Pustaka Utama.

Iqbal, M. S., \& Seo, J. W. (2008). E-governance as an anti corruption tool: Korean cases. Journal of Korean Association for Regional Information Society, 11(2), 51-78.

Ismail, R. (2012). Keberagamaan koruptor menurut psikologi (Tinjauan orientasi keagamaan dan psikografi agama). Esensia: Jurnal Ilmu-Ilmu Ushuluddin, 13(2), 289-304.

Jain, A. K. (2001). Corruption: A review. Journal of Economic Surveys, 15(1), 71-121.

Jain A. K., \& Ramani A. K. (2005). Concepts and applications of e-governance: Illustrations through some case studies. Journal of the Eighth National Conference on e-Governance, 65-71.

Millard, J. (2004). (R)e-balancing government. Denmark: Danish Technological Institute.

NeGP Report. (2007). Draft Report of the first phase of NeGP Impact Assessment Study. Ahmedabad: Indian Institute of Management, Ahmedabad. Accessed on November 6, 2008 from http://mit.gov.in/

Nye, J. S. (1989). Corruption and political development: A cost-benefit analysis. In A. J. Heidenheimer, M. Johnston, \& T. Victor (Eds.). 
Political corruption: A handbook (pp. 963-965). New Brunswick: Transaction Publishers.

Ojha, A., Palvia, S., \& Gupta, M. P. (2008). A model for impact of e-government on corruption: Exploring theoretical foundations. In J. Bhattacharya (Ed.), Critical thinking in e-governance (pp. 160-170). New Delhi: Gift Publishing.

Paloutzian, R. F. (1996). Invitation to the psychology of religion ( $2^{\text {nd }}$ ed.). Needham Heights, MA: Allyn \& Bacon.

Pathak, R. D., \& Prasad, R. S. (2006). Role of e-governance in tackling corruption: The Indian experience. In R. Ahmad (Ed.), The role of public administration in building a harmonious society (pp. 434-463). Philippines: Asian Development Bank.

Rakhmat, J. (2004). Psikologi agama: Sebuah pengantar. Bandung: Mizan

Ramamoorti, S. (2008). The psychology and sociology of fraud: Integrating the behavioral sciences component into fraud and forensic accounting curricula. Issues in Accounting Education, 23(4), 521-533.

Rotchanakitumnuai, S. (2013). The governance evidence of e-government procurement. Transforming Government: People, Process and Policy. 7(3), 309-321.

Shaleh, H. A. (2002). Takwa: Makna dan hikmahnya dalam Al-Qur'an. Penerbit Erlangga.

Shamsudin, F. M., Chauhan, A., \& Kura, K. M. (2012). Self-control as a moderator of the relationship between formal control and workplace deviance: A proposed framework. Australian Journal of Business and Management Research, 2(6), 32-39.

Suartana, I. W. (2010). Behavioral accounting: Theory and implementation. Yogyakarta: Penerbit ANDI. 
Vaidya, K., Sajeev, A. S. M., \& Callender, G. (2006). Critical factors that influence e-procurement implementation success in the public sector. Journal of Public Procurement, 6, 70-99.

Wilopo, W. (2006). Analysis of factors affecting on the accounting fraud: Studies on public companies and state-owned enterprises. Padang: SNA IX Publications. 